\title{
Activities of Extracts and Compounds from Spiranthera odoratissima St. Hil. (Rutaceae) in Leaf-cutting Ants and their Symbiotic Fungus
}

\author{
Ana Paula Terezan, ${ }^{a}$ Raquel Andrade Rossi, ${ }^{b}$ Roberta N. A. Almeida, ${ }^{b}$ \\ Taís Garcia Freitas, ${ }^{b}$ João B. Fernandes, ${ }^{*}, a$ M. Fátima das Graças Fernandes da Silva, ${ }^{a}$ \\ Paulo C. Vieira, ${ }^{a}$ Odair C. Bueno, ${ }^{b}$ Fernando C. Pagnocca ${ }^{b}$ and José R. Pirani ${ }^{c}$ \\ ${ }^{a}$ Departamento de Química, Universidade Federal de São Carlos, CP 676, \\ 13565-905 São Carlos-SP, Brazil \\ ${ }^{b}$ Centro de Estudos de Insetos Sociais, Universidade Estadual Paulista, Campus Rio Claro, \\ CP 199, 13506-900 Rio Claro-SP, Brazil \\ ${ }^{c}$ Departamento de Botânica, Instituto de Biociências, Universidade de São Paulo, \\ 05508-900 São Paulo-SP, Brazil
}

\begin{abstract}
O estudo dos extratos dos galhos da planta Spiranthera odoratissima St. Hil. (Rutaceae) levou ao isolamento de alcalóides furoquinolínicos (dictamina, $\gamma$-fagarina e esquimianina) e 2 -arilquinolin4-ona (2-fenil-1-metilquinolin-4-ona) e limonóides (ácido limonéxico e limonina). Os compostos 2-fenil-1-metilquinolin-4-ona e ácido limonéxico foram isolados pela primeira vez no gênero Spiranthera. Os alcalóides furoquinolínicos, 2-arilquinolin-4-ona e os limonóides mostraram atividade inseticida e/ou fungicida no ninho da formiga Atta sexdens rubropilosa.
\end{abstract}

The study of the Spiranthera odoratissima St. Hil (Rutaceae) branches extracts led to the isolation of the furoquinoline (dictamine, $\gamma$-fagarine and skimmianine) and 2-arylquinoli-4-one (1-methyl-2-phenylquinolin-4-one) alkaloids and limonoids (limonexic acid and limonin). The compounds 1-methyl-2-phenylquinolin-4-one and limonexic acid were isolated for the first time from the Spiranthera. These furoquinoline and 2-arylquinoli-4-one alkaloids and limonoids showed insecticidal and/or fungicidal activity in the nest of the Atta sexdens rubropilosa.

Keywords: Spiranthera odoratissima, furoquinoline alkaloids, limonoids, Atta sexdens rubropilosa, Leucoagaricus gongylophorus

\section{Introduction}

Spiranthera odoratissima St. Hil. (Rutaceae), popularly know as Manacá, is a shrub found in the savannah and forest of Central Brazil, and in Bolivia. ${ }^{1}$ In folk medicine is used in the treatment of rheumatism, gout, kidney infections, urinary retention, abdominal pains, acne and boil. ${ }^{2}$ According to Matos et al., ${ }^{3}$ the ethanolic extract of the $S$. odoratissima roots contain compounds with analgesic and anti-inflammatory activity.

In previous phytochemical studies of S. odoratissima roots and leaves were reported to contain furoquinoline and $\beta$-indoloquinazoline alkaloids, coumarin, terpene, steroid and limonoids. ${ }^{4-5}$

\footnotetext{
*e-mail:djbf@power.ufscar.br
}

Leaf-cutting ants (Hymenoptera) are dominant herbivores in the tropics and can be found from the United States Southern to Northern Argentina countries. ${ }^{6}$ They cultivate a symbiotic fungus for feeding using leaf fragments as substrate, thus they are considering plague. ${ }^{7}$ Therefore, the biological control of these insects has been the aim of many studies.

In this work was determined the toxicity of crude extract and compounds isolated from $S$. odoratissima branches in nest of the Atta sexdens rubropilosa.

\section{Experimental}

General experimental procedures

The ${ }^{1} \mathrm{H}$ NMR, ${ }^{13} \mathrm{C}$ NMR and 2D correlations spectra were obtained using Bruker DRX-400 spectrometer, with $\mathrm{CDCl}_{3}$ and acetone- $d_{6}$ using TMS as internal standard. 
For ESIMS analysis, low resolution, was used on triple quadrupole Micromass Quattro LC instrument. GC/MS (EI) analysis was used a QP5000 Shimadzu, capillary column DB $5 \mathrm{MS}(30 \mathrm{~m}, 0.25 \mathrm{~mm}$ id, film $0.25 \mu \mathrm{m})$. The temperature was programmed initially at $70^{\circ} \mathrm{C}$ for $4 \mathrm{~min}$, them increased with a rate of $10^{\circ} \mathrm{C} \mathrm{min}^{-1}$ to $280^{\circ} \mathrm{C}$ respectively, injection volume was $1 \mu \mathrm{L}$ in a split mode and temperatures of the detector/ injector were $300 / 280{ }^{\circ} \mathrm{C}$. The mass selective detector at $70 \mathrm{eV}$ with scans from 50 to $500 \mathrm{u}$.

\section{Plant material}

Branches of S. odoratissima were collected in Rio Verde-Jataí, GO, Brazil in January/2001 and identified by Dr. José Rubens Pirani. Voucher specimens (4778) were deposited at the Institute of Bioscience herbarium of the University of São Paulo.

\section{Compounds extraction and isolation}

The dried and powdered branches $(1.1 \mathrm{~kg})$ were subsequently extracted with $n$-hexane $(1.9 \mathrm{~g}), \mathrm{CH}_{2} \mathrm{Cl}_{2}$ $(7.2 \mathrm{~g})$ and $\mathrm{MeOH}(16.7 \mathrm{~g})$. The concentrated $\mathrm{CH}_{2} \mathrm{Cl}_{2}$ extract was submitted to vacuum chromatography over silica gel (70-230 mesh) using a $n$-hexane- $\mathrm{CH}_{2} \mathrm{Cl}_{2}$-EtOAc$\mathrm{MeOH}$ gradient. The $\mathrm{CH}_{2} \mathrm{Cl}_{2}$-EtOAc fraction $(4.1 \mathrm{~g})$ was chromatographed on silica gel (230-400 mesh), eluting with a $n$-hexane- $\mathrm{CH}_{2} \mathrm{Cl}_{2}$-EtOAc-MeOH gradient to give 3 fractions A-C. Fraction A (34.4 mg) was fractionated as above, $n$-hexane- $\mathrm{CH}_{2} \mathrm{Cl}_{2}$-EtOAc gradient. The fraction A-1 $(15.0 \mathrm{mg})$ was purified by preparative TLC using $n$-hexane$\mathrm{CH}_{2} \mathrm{Cl}_{2}(1: 4)$ yielding 1 (7.8 mg). Fraction B $(689.3 \mathrm{mg})$ was fractionated using $n$-hexane- $\mathrm{CH}_{2} \mathrm{Cl}_{2}$-EtOAc-MeOH gradient yielding 26 fractions. The fraction $\mathrm{B}-15(37.0 \mathrm{mg})$ was purified by preparative TLC using $n$-hexane- $\mathrm{CH}_{2} \mathrm{Cl}_{2}$ (1:4) yielding $2(8.7 \mathrm{mg})$. Fraction B-16 (210.1 mg) was fractionated using $n$-hexane- $\mathrm{CH}_{2} \mathrm{Cl}_{2}$-acetone (3.5:6:0.5) and yielded 32 fractions. The fraction B-16.27 $(44.5 \mathrm{mg})$ was purified by preparative TLC using hexane- $\mathrm{CH}_{2} \mathrm{Cl}_{2}$ acetone (0.5:4:0.5) yielding 3 (7.4 mg). Fraction C (2.1 g) was fractionated using $n$-hexane- $\mathrm{CH}_{2} \mathrm{Cl}_{2}$-EtOAc- $\mathrm{MeOH}$ gradient, yielding 70 fractions. The fraction $\mathrm{C}-34$ (397.5 mg) was fractionated using $n$-hexane- $\mathrm{CH}_{2} \mathrm{Cl}_{2}$ EtOAc-MeOH gradient and fraction C-34.86 was purified by preparative TLC using $\mathrm{CH}_{2} \mathrm{Cl}_{2}$-acetone (4:1) and yielded 4 (18.0 mg). Fraction C-67 (40.4 mg) was fractionated by TLC using $\mathrm{CH}_{2} \mathrm{Cl}_{2}-\mathrm{MeOH}$ (2:3) yielding 5 (5.0 mg). The concentrated $\mathrm{MeOH}$ extract was submitted to liquid partition with $n$-hexane, $\mathrm{CH}_{2} \mathrm{Cl}_{2}$, EtOAc and $\mathrm{MeOH}$. The union of the $n$-hexane and $\mathrm{CH}_{2} \mathrm{Cl}_{2}$ fractions $(510.0 \mathrm{mg})$ was chromatographed on Sephadex LH-20 eluting with
$\mathrm{MeOH}, \mathrm{MeOH}-\mathrm{CH}_{2} \mathrm{Cl}_{2}(4: 1,3: 2$ and 1:1) to give 38 frations. Fraction $22(89.0 \mathrm{mg})$ was submitted to centrifugational chromatography (Cromatroton) using $n$-hexane- $\mathrm{CH}_{2} \mathrm{Cl}_{2}-$ EtOAc-MeOH gradient, yielding 10 fractions. Fraction 22-2 (20.0 mg) was purified by preparative TLC using $n$-hexane- $\mathrm{CH}_{2} \mathrm{Cl}_{2}$-acetone (1:8:1) and yielded $\mathbf{6}(16.0 \mathrm{mg})$.

\section{Identification of the isolated compounds}

The isolated compounds were identified using NMR, MS techniques. The furoquinoline alkaloids, dictamine (1), $\gamma$-fagarine (2) and skimmianine (3) presented spectral data in agreement with the literature. ${ }^{8-9} 1$-Methyl-2phenylquinolin-4-one (4) ${ }^{10}$ : Amorphous solid, EIMS m/z (rel. int. \%) $\left[\mathrm{M}^{+}\right] 235$ (100), 207 (71), 178 (6), 165 (11), 102 (19), 89 (9), 77 (17), 51 (11). Limonexic acid (5) ${ }^{11}$ : Amorphous solid. ESIMS, m/z (rel. int. \%): 501 [M-H] ${ }^{-}$ (100). Limonin $(6)^{11}$ : white solid, mp $295-299^{\circ} \mathrm{C}$; ESIMS, $\mathrm{m} / \mathrm{z}$ (rel. int. \%): 469 [M-H]- (100).

\section{Fungicidal bioassay}

The fungus Leucoagaricus gongylophorus (Singer) Möller (syn Rozites gongylophorus) was isolated from an Atta sexdens rubropilosa laboratory nest.

The medium for fungus maintenance and methods for the bioassays were previously described..$^{12}$ Solvent ( $n$-hexane or dichloromethane or methanol) or solution of each extract or solution of compounds $(1.0 \mathrm{~mL})$ were added to $9.0 \mathrm{~mL}$ of culture medium composed of $\left(\mathrm{g} \mathrm{L}^{-1}\right)$ : glucose (10.0), sodium chloride (5.0), peptone (5.0), malt extract (10.0) and agar (15.0). Control tubes received $1.0 \mathrm{~mL}$ of solvent and $9.0 \mathrm{~mL}$ of medium. After the addition, the tubes were autoclaved at $121{ }^{\circ} \mathrm{C}$ by $15 \mathrm{~min}$ and then slanted. The final concentration of $n$-hexane, $\mathrm{CH}_{2} \mathrm{Cl}_{2}$ and $\mathrm{MeOH}$ extracts were $1000 \mu \mathrm{g} \mathrm{mL}^{-1}$ and of the compounds $\mathbf{1 , 2}$ and 3 were $50 \mu \mathrm{g} \mathrm{mL}^{-1}$. The fungal suspension was prepared by transferring aseptically pieces of the mycelia (obtained from 1-month-old culture growing in slant culture) to an all-glass tissue grinder containing sterile peptone $\left(1.0 \mathrm{~g} \mathrm{~L}^{-1}\right)$ and gently fragmented. This suspension $(1.0 \mathrm{~mL})$ was spread onto the surface of the agar slant and incubated at $25( \pm 1){ }^{\circ} \mathrm{C}$ for 30 days. The assays were run twice (two sets of five tubes each). Fungal growth was estimated macroscopically on the basis of the mycelial surface and density using the modal value.

\section{Leaf-cutting ant insecticide biossay}

The A. sexdens rubropilosa workers used in the assays were randomly removed from laboratory nests. They had 
a body mass of 20-25 mg. Before the assays the nests were supplied daily with leaves of Eucalyptus sp., oat seeds and occasionally with leaves of other plants such as Hibiscus sp., Ligustrum sp. or rose petals. Fifty ants were removed from the nests and put into five Petri dishes (ten ants each) for each treatment. During the assay the ants were maintained on an artificial diet prepared with glucose $\left(50.0 \mathrm{~g} \mathrm{~L}^{-1}\right)$, bacto-peptone $\left(10.0 \mathrm{~g} \mathrm{~L}^{-1}\right)$, yeast extract $\left(1.0 \mathrm{~g} \mathrm{~L}^{-1}\right)$, and agar $\left(15.0 \mathrm{~g} \mathrm{~L}^{-1}\right)$, in distilled water $(100 \mathrm{~mL}) \cdot{ }^{13}$ The diet $(0.4-0.5 \mathrm{~g}$ per dish) with the addition of compounds (experiment) or without (control) were offered daily in a small plastic cap. The control was prepared with the diet and the solvent. To ensure that undetectable remaining amounts of the solvent did not affect the ants, a comparison made with another set of dishes in which water was used instead of solvent. As expected, the same survival rates were obtained with both systems (data not shown). The compounds were poured into the hot diet immediately after it was autoclaved. The final concentration of the extracts added to the diet were $2000 \mu \mathrm{g} \mathrm{mL}^{-1}$ and of the compounds $100 \mu \mathrm{g} \mathrm{mL}^{-1}$ or $500 \mu \mathrm{g} \mathrm{mL}^{-1}$. During the assays the material was maintained in an incubator at a temperature $25( \pm 1){ }^{\circ} \mathrm{C}$ and relative humidity ranging between $70-80 \%$. The maximum length of observation was 25 days and number of dead ants was registered daily.

The survival median $50 \%\left(\mathrm{~S}_{50}\right)$ was calculated and survival curves were compared by the computer-assisted software Graph-Pad ${ }^{\mathrm{TM}}$ using the log-rank test.

\section{Results and Discussion}

The compounds isolated from dichloromethane crude extract of the $S$. odoratissima branches were dictamine ${ }^{8}$ (1), $\gamma$-fagarine ${ }^{9}$ (2), skimmianine ${ }^{8}$ (3), 1-methyl-2phenylquinolin-4-one (4), limonexic acid (5) and limonin (6) (Figure 1). The 1-methyl-2-phenylquinolin-4-one (4) and limonexic acid (5) were isolated for the first time from the Spiranthera.

Compounds 1-3 were identified by comparison of NMR spectral data with those described in the literature, ${ }^{8,9}$ and the structures of compounds $\mathbf{4}, \mathbf{5}$ and $\mathbf{6}$ were confirmed on the basis of ${ }^{1} \mathrm{H}$ NMR, EIMS and ESIMS spectra, and carbon attributions that were made by HSQC and HMBC correlation spectra.

The $S$. odoratissima branches crude extracts showed high inhibitory activity on L. gongylophorus growth and dichloromethane and methanolic extracts present insecticidal activity on A. sexdens rubropilosa ants.

The $n$-hexane, dichloromethane and methanol crude extract $\left(1000 \mu \mathrm{g} \mathrm{mL}^{-1}\right)$ showed $100 \%$ of inhibitory activity on symbiotic fungus (L. gongylophorus). The activities of

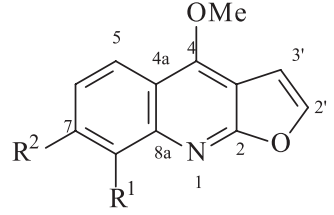

(1) $\mathrm{R}^{1}=\mathrm{R}^{2}=\mathrm{H}$

(2) $\mathrm{R}^{1}=\mathrm{OMe} ; \mathrm{R}^{2}=\mathrm{H}$

(3) $\mathrm{R}^{1}=\mathrm{R}^{2}=\mathrm{OMe}$

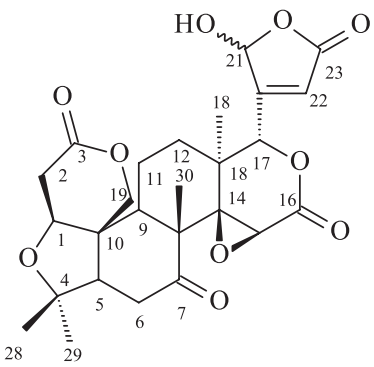

(5)

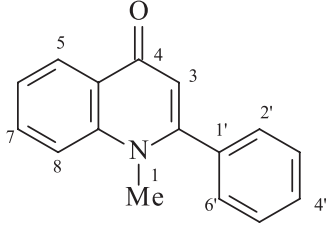

(4)

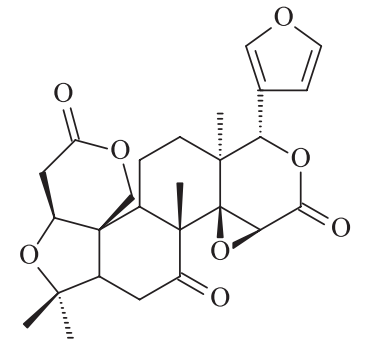

(6)
Figure 1. Molecular structures of the compounds isolated from S. odoratissima branches extracts: 1: dictamine, 2: $\gamma$-fagarine, 3: skimmianine, 4: 1-methyl-2-phenylquinolin-4-one, 5: limonexic acid and 6: limonin.

compounds 1-3 were comparable to those of extracts above. However, $\mathbf{1}$ and $\mathbf{2}$ were more fungicide than $\mathbf{3}$, the two first inhibiting fungus growths at $100 \%$ and the later $80 \%$. The compounds $\mathbf{4 , 5}$ and $\mathbf{6}$, were not tested in this bioassay. These results suggest that the furoquinoline alkaloids are the potentially active compounds in the fungicidal bioassay of dichloromethane crude extract. The fungicidal activity of furoquinoline alkaloids skimmianine, kokusaginine, maculine, dictamine, flindersiamine and quinolone obtained from Rutaceae family, ${ }^{10,14}$ already had been described in literature as powerful inhibitors of symbiotic fungus growth.

The $n$-hexane, dichloromethane and methanolic extracts were tested in ants (A. sexdens rubropilosa) ingestion bioassay (Table 1) and dichloromethane and methanolic extracts present insecticidal activity. In contrast with high fungicidal activity of furoquinoline alkaloids against the symbiotic fungus of the leaf-cutting ants, the ingestion bioassay showed that compounds $\mathbf{1}$ and $\mathbf{2}$ showed weak activity in ants ingestion assay, which had $\mathrm{S}_{50}$ ranging from 11.0 and 14.0, respectively, while in the control $S_{50}$ was 15.0. Only compound $\mathbf{1}$ presented statistic difference in comparison with control (Table 2), according to the logrank test $(p<0.05)$, which considered all tested period. Compound $\mathbf{3}$ was tested in previous work ${ }^{15}$ and showed not be toxic to the leaf-cutting ants. Compounds 4-6 isolated from dichloromethane and methanolic extracts showed toxicity against leaf-cutting ants (Table 3 ). The ants survival median $\left(\mathrm{S}_{50}\right)$ were in the $7^{\text {th }}$ and $4^{\text {th }}$ day of the experiment, respectively, compared with the control $\left(S_{50}=12\right.$ days $)$ for 
Table 1. Atta sexdens rubropilosa workers mortality (\%) and Survival median (S50) when fed with diet containing crude extracts $\left(2000 \mu \mathrm{g} \mathrm{mL}^{-1}\right)$ from Spiranthera odoratisssima branches

\begin{tabular}{|c|c|c|c|c|c|c|c|c|c|c|c|}
\hline \multirow[t]{2}{*}{ Crude extracts } & \multicolumn{10}{|c|}{ days } & \multirow[t]{2}{*}{$\mathrm{S}_{50}$} \\
\hline & 1 & 2 & 3 & 6 & 8 & 10 & 14 & 17 & 21 & 25 & \\
\hline Control & 0 & 0 & 0 & 0 & 8 & 18 & 30 & 46 & 60 & 88 & $18.0^{\mathrm{a}}$ \\
\hline$n$-Hexane & 0 & 0 & 0 & 8 & 12 & 22 & 38 & 54 & 90 & 94 & $17.0^{\mathrm{b}}$ \\
\hline Dichloromethane & 0 & 2 & 16 & 56 & 76 & 86 & 96 & 98 & 100 & - & $5.5^{\mathrm{c}}$ \\
\hline Methanol & 0 & 2 & 18 & 36 & 80 & 92 & 98 & 98 & 100 & - & $5.0^{\mathrm{c}}$ \\
\hline
\end{tabular}

${ }^{\mathrm{b}}$ significant difference according to the long-rank test (b: $0.01<p<0.05$ ). ${ }^{\mathrm{c}}$ significant difference according to the long-rank test (c: $p<0.01$ ).

Table 2. Atta sexdens rubropilosa workers mortality (\%) and survival median $\left(\mathrm{S}_{50}\right)$ when fed with compounds $\mathbf{1 - 2}\left(100 \mu \mathrm{g} \mathrm{mL}^{-1}\right)$ isolated from Spiranthera odoratisssima branches

\begin{tabular}{|c|c|c|c|c|c|c|c|c|c|c|c|}
\hline \multirow[t]{2}{*}{ Compounds } & \multicolumn{10}{|c|}{ days } & \multirow[t]{2}{*}{$\mathrm{S}_{50}$} \\
\hline & 1 & 2 & 3 & 6 & 8 & 10 & 14 & 17 & 21 & 25 & \\
\hline Control & 0 & 2 & 2 & 6 & 8 & 14 & 38 & 60 & 72 & 86 & $15.0^{\mathrm{a}}$ \\
\hline Dictamine (1) & 0 & 0 & 0 & 20 & 36 & 48 & 64 & 74 & 86 & 96 & $11.0^{\mathbf{b}}$ \\
\hline$\gamma$-Fagarine (2) & 0 & 0 & 0 & 6 & 18 & 26 & 54 & 64 & 76 & 80 & $14.0^{\mathrm{a}}$ \\
\hline
\end{tabular}

${ }^{\mathrm{b}}$ significant difference according to the long-rank test (b: $\left.p<0.05\right)$.

Table 3. Atta sexdens rubropilosa workers mortality $(\%)$ and Survival median $\left(\mathrm{S}_{50}\right)$ when fed with compounds 4-6 $\left(500 \mu \mathrm{g} \mathrm{mL}^{-1}\right)$ isolated from Spiranthera odoratisssima branches

\begin{tabular}{|c|c|c|c|c|c|c|c|c|c|c|c|}
\hline \multirow[t]{2}{*}{ Compounds } & \multicolumn{10}{|c|}{ days } & \multirow[t]{2}{*}{$\mathrm{S}_{50}$} \\
\hline & 1 & 2 & 3 & 6 & 8 & 10 & 14 & 17 & 21 & 25 & \\
\hline Control & 2 & 14 & 24 & 32 & 32 & 32 & 68 & 72 & 72 & 76 & $12.0^{\mathrm{a}}$ \\
\hline 1-Methyl-2-phenylquinolin-4-one (4) & 0 & 8 & 28 & 46 & 58 & 60 & 84 & 86 & 94 & 96 & $7.0^{\mathbf{b}}$ \\
\hline Limonexic acid (5) & 8 & 46 & 66 & 84 & 84 & 84 & 92 & 98 & 100 & 100 & $3.0^{\mathbf{b}}$ \\
\hline Limonin $(6)$ & 2 & 28 & 46 & 60 & 62 & 72 & 88 & 94 & 96 & 96 & $4.0^{\mathbf{b}}$ \\
\hline
\end{tabular}

${ }^{\mathrm{b}}$ significant difference according to the long-rank test (b: $p<0.05$ ).

1-methyl-2-phenylquinolin-4-one (4) and limonin (6) in concentration of $500 \mu \mathrm{g} \mathrm{mL}^{-1}$. For limonexic acid (5), the most potent compound, at concentration of $500 \mu \mathrm{g} \mathrm{mL}^{-1}$, the survival median $\left(\mathrm{S}_{50}\right)$ of the ants were in the $3^{\text {rd }}$ day of the experiment and $98 \%$ mortality occurred at the $17^{\text {th }}$ day. This latter result was also observed by Biavatti et al. ${ }^{16}$ Therefore, these results indicate that the compounds 4-6 are potentially active compounds against $A$. sexdens rubropilosa.

The potential insecticidal and fungicidal activities of the $S$. odoratissima extracts and of the compounds isolated from the dichloromethane and methanolic extracts suggest the use of this plant in the nest of the leaf-cutting ants control, and the continuation of the investigation of the S. odoratissima bioactive compounds.

\section{Supplementary Information}

Supplementary data are available free of charge at http://jbcs.sbq.org.br, as PDF file.

\section{Acknowledgements}

The authors are grateful to Conselho Nacional de Desenvolvimento Científico e Tecnológico (CNPq), Fundação de Amparo à Pesquisa do Estado de São Paulo (FAPESP), Coordenação de Aperfeiçoamento de Pessoal de Ensino Superior (CAPES) by financial support.

\section{References}

1. Pirani, J. R.; Free Teaching Thesis, Estudos Taxonômicos de Rutaceae, Universidade de São Paulo, Brazil, 1999.

2. De-La Cruz, M. G. F.; MSc Dissertation, Universidade Federal de Mato Grosso, Brazil, 1997.

3. Matos, L. G.; Pontes, I. S.; Tresvenzol, L. M. F.; Paula, J. R.; Costa, E. A.; Phytother. Res. 2005, 18, 963.

4. Ribeiro, T. A. N.; Ndiaye, E. A. S.; Velozo, E. S.; Vieira, P. C.; Ellena, J.; Sousa Jr., P. T.; J. Braz. Chem. Soc. 2005 , $16,1347$. 
5. Freitas, C. M. D.; Lucchese, A. M.; Silva, F. S.; Velozo, E. D.; Biochem. Syst. Ecol. 2003, 31, 805.

6. Mariconi, F. A. M.; As Saúvas, Agronômica Ceres: São Paulo, 1970.

7. Weber, N. A.; Mem. Am. Philos. Soc. 1972, 92, 17.

8. Facundo, V. A.; da Silveira, A. S.; Braz-Filho., R.; Pinto, A. C.; Rezende, C. M.; Quim. Nova 2005, 28, 224.

9. Tillequin, F.; Koch, M.; Sevenet, T. H.; Planta Med. 1980, 38, 3830 .

10. Biavatti, M. W.; Vieira, P. C.; da Silva, M. F. G. F.; Fernandes, J. B.; Victor, S. R.; Pagnocca, F. C.; Albuquerque, S.; Caracelli, I.; Zukerman-Schpector, J.; J. Braz. Chem. Soc. 2002, 13, 66.

11. Biavatti, M. W.; Vieira, P. C.; da Silva, M. F. G. F.; Fernandes, J. B.; Albuquerque, S.; Z. Naturforsch., C: J. Biosci. 2001, 56, 570.

12. Pagnocca, F. C.; Silva, O. A.; Hebling, M. J. A.; Bueno, O. C.; Bull. Entomol. Res. 1990, 80, 349.
13. Bueno, O. C.; Moroni, M. S. C.; Pagnocca, F. C.; Hebling, M. J. A.; Silva, O. A.; An. Soc. Entomol. Bras. 1997, 26, 107.

14. Almeida, R. N. A.; Peñaflor, M. F. G. V.; Simote, S. Y.; Bueno, O. C.; Hebling, M.J. A.; Pagnocca, F. C.; Fernandes, J. B.;Vieira, P. C.; da Silva, M. F. G. F.; Bioassay 2007, 2, 2.

15. Simote, S. Y.; PhD Thesis, Universidade Federal de São Carlos, Brazil, 2006.

16. Biavatti, M. W.; Westerlon, R.; Vieira, P. C.; da Silva, M. F. G. F.; Fernandes, J. B.; Peñaflor, M. F. G. V.; Bueno, O. C.; Ellena, J.; J. Braz. Chem. Soc. 2005, 16, 1443.

Received: March 11, 2009

Web Release Date: February 11, 2010

FAPESP helped in meeting the publication costs of this article. 


\section{Activities of Extracts and Compounds from Spiranthera odoratissima St. Hil. (Rutaceae) in Leaf-cutting Ants and their Symbiotic Fungus}

Ana Paula Terezan, ${ }^{a}$ Raquel Andrade Rossi, ${ }^{b}$ Roberta N. A. Almeida, ${ }^{b}$

Taís Garcia Freitas, ${ }^{b}$ João B. Fernandes, ${ }^{*}, a$ M. Fátima das Graças Fernandes da Silva, ${ }^{a}$ Paulo C. Vieira, ${ }^{a}$ Odair C. Bueno, ${ }^{b}$ Fernando C. Pagnocca ${ }^{b}$ and José R. Pirani ${ }^{c}$

${ }^{a}$ Departamento de Química, Universidade Federal de São Carlos, CP 676,

13565-905 São Carlos-SP, Brazil

${ }^{b}$ Centro de Estudos de Insetos Sociais, Universidade Estadual Paulista, Campus Rio Claro, CP 199, 13506-900 Rio Claro-SP, Brazil

${ }^{c}$ Departamento de Botânica, Instituto de Biociências, Universidade de São Paulo, 05508-900 São Paulo-SP, Brazil

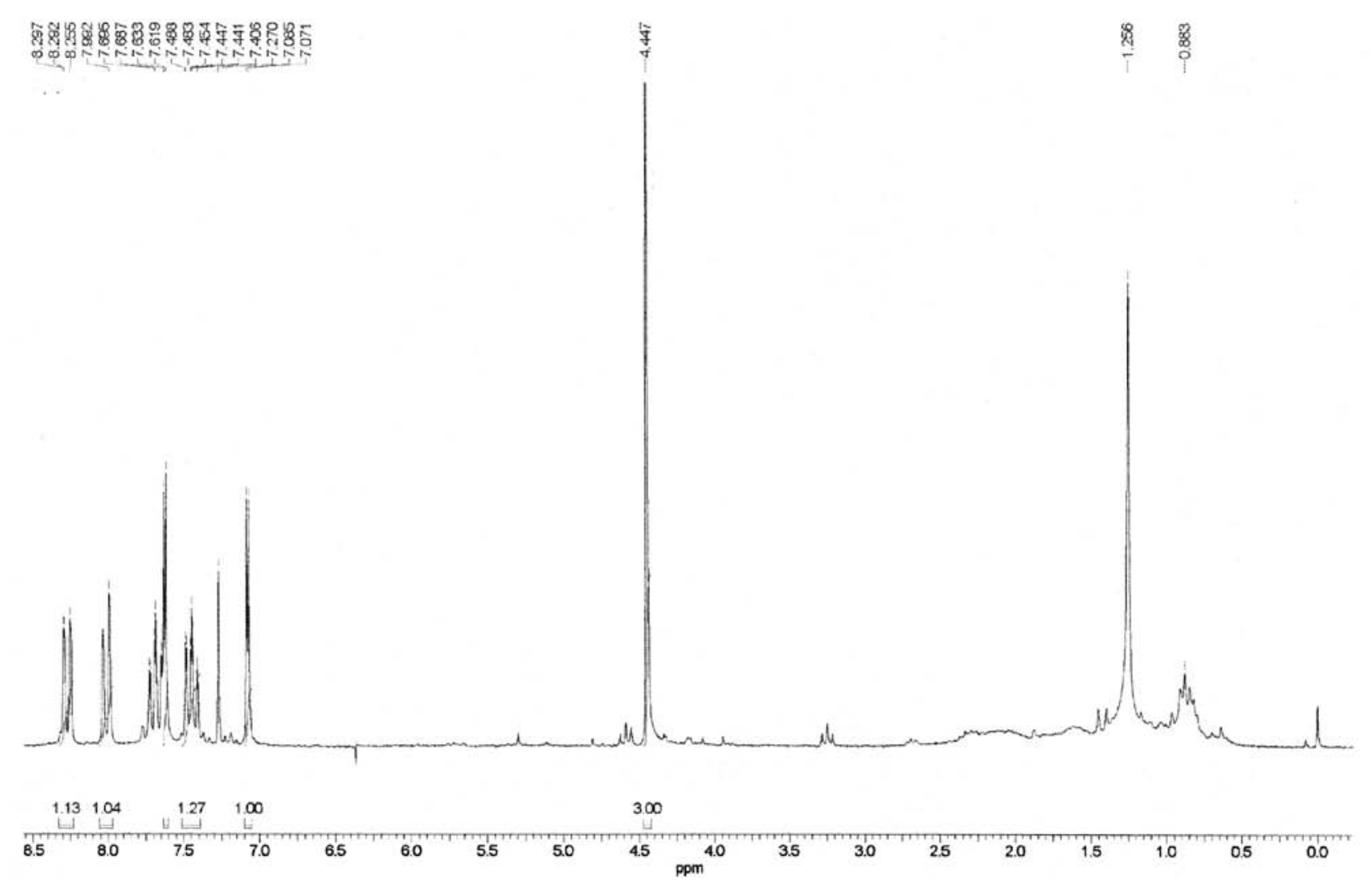

Figure S1. ${ }^{1} \mathrm{H}$ NMR spectrum of dictamine $\left(\mathrm{CDCl}_{3}, 200 \mathrm{MHz}\right)$. 


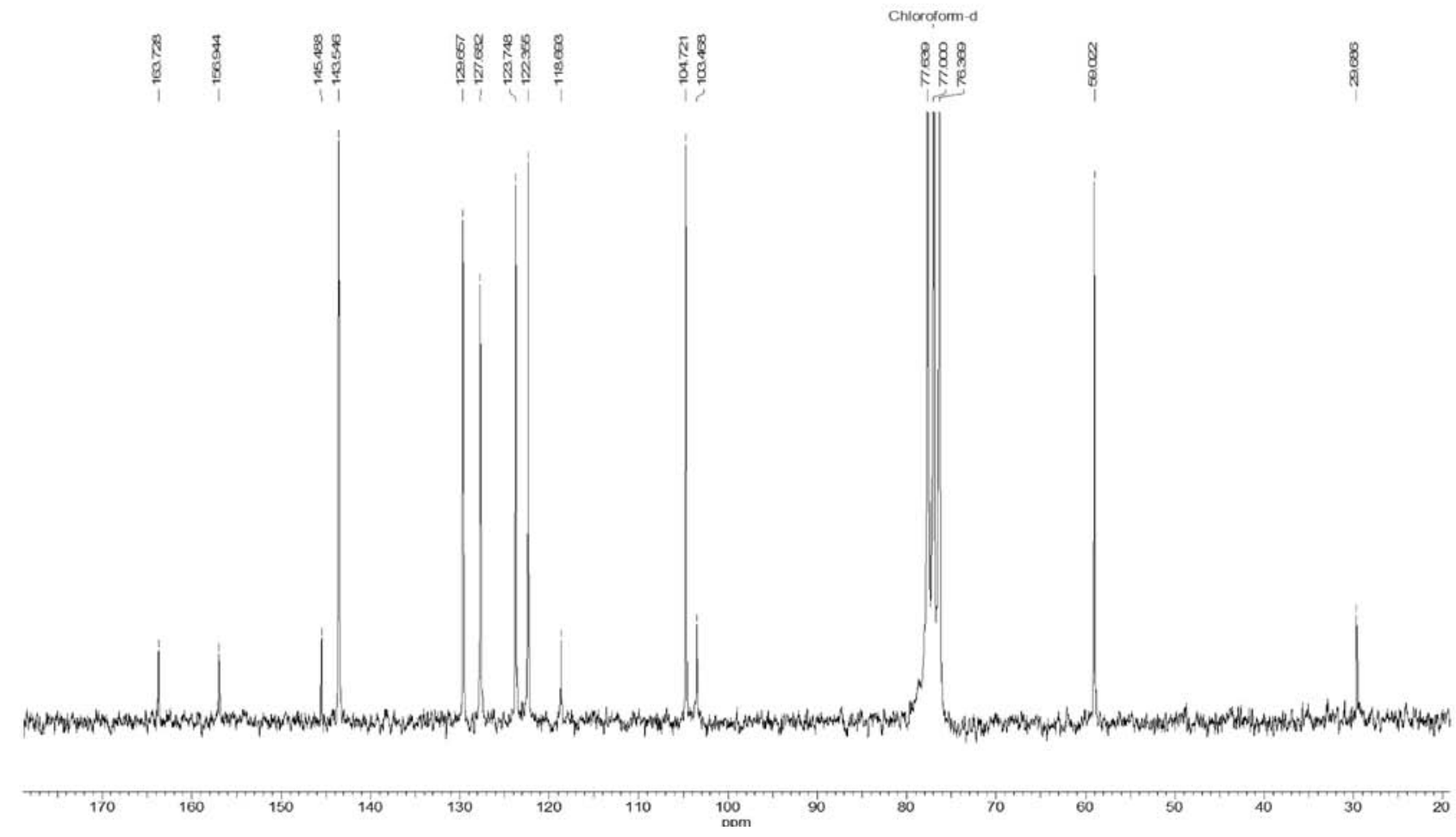

Figure S2. ${ }^{13} \mathrm{C}$ NMR spectrum of dictamine $\left(\mathrm{CDCl}_{3}, 200 \mathrm{MHz}\right)$.

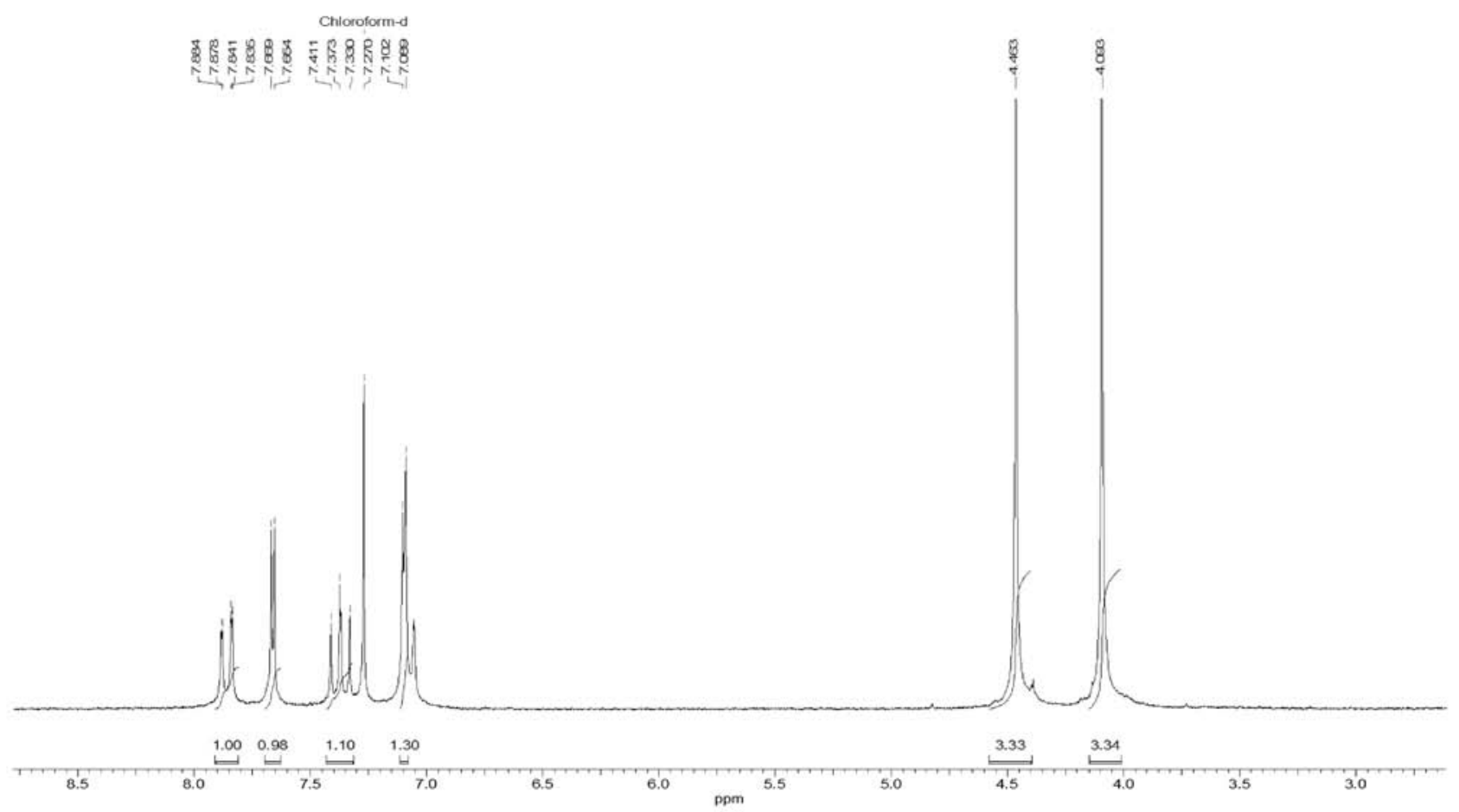

Figure S3. ${ }^{~} \mathrm{H}$ NMR spectrum of $\gamma$-fagarine $\left(\mathrm{CDCl}_{3}, 200 \mathrm{MHz}\right)$. 


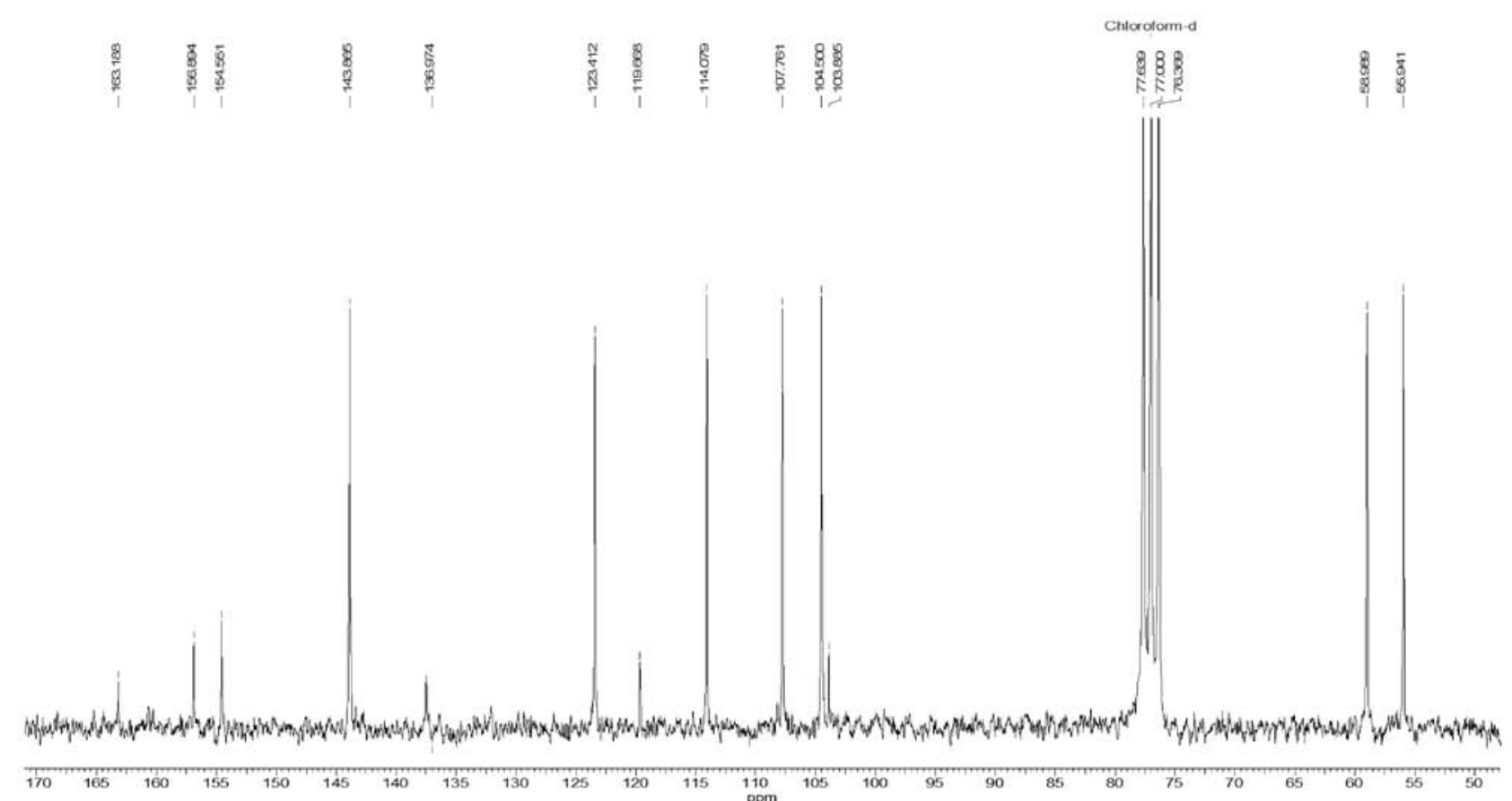

Figure S4. ${ }^{13} \mathrm{C}$ NMR spectrum of $\gamma$-fagarine $\left(\mathrm{CDCl}_{3}, 200 \mathrm{MHz}\right)$.

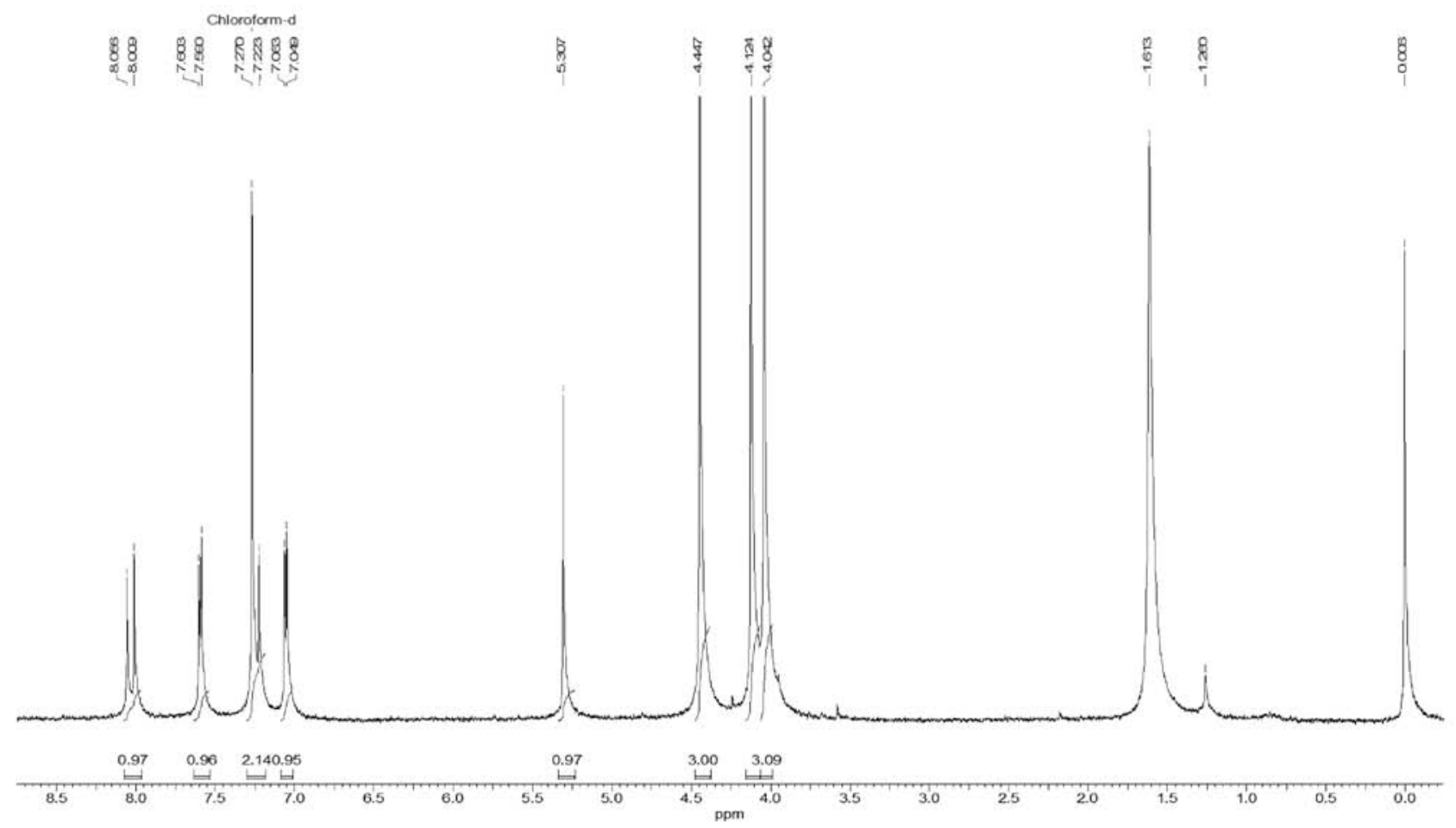

Figure S5. ' $\mathrm{H}$ NMR spectrum of skimmianine ( $\left.\mathrm{CDCl}_{3}, 200 \mathrm{MHz}\right)$. 


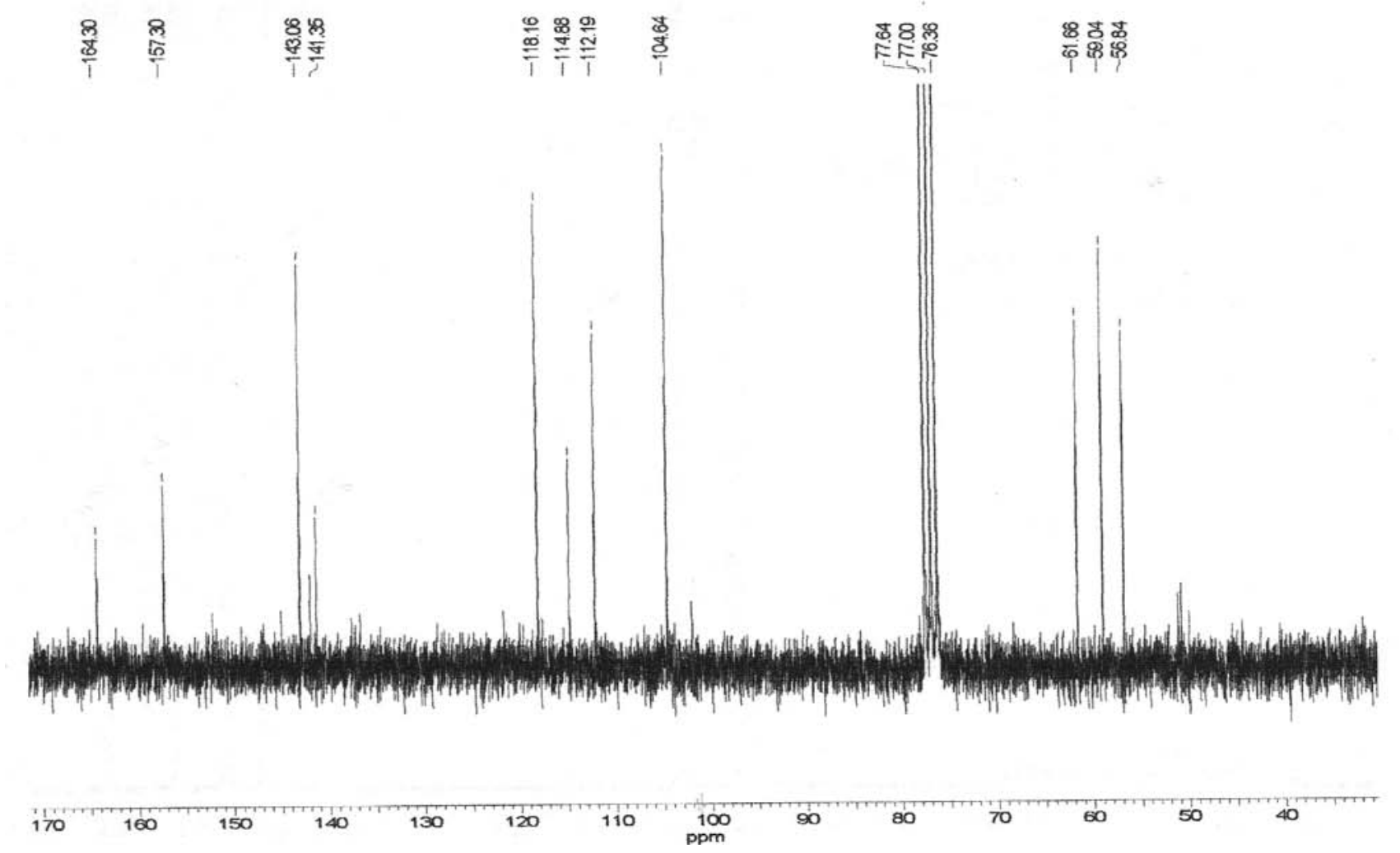

Figure S6. ${ }^{13} \mathrm{C}$ NMR spectrum of skimmianine $\left(\mathrm{CDCl}_{3}, 200 \mathrm{MHz}\right)$.
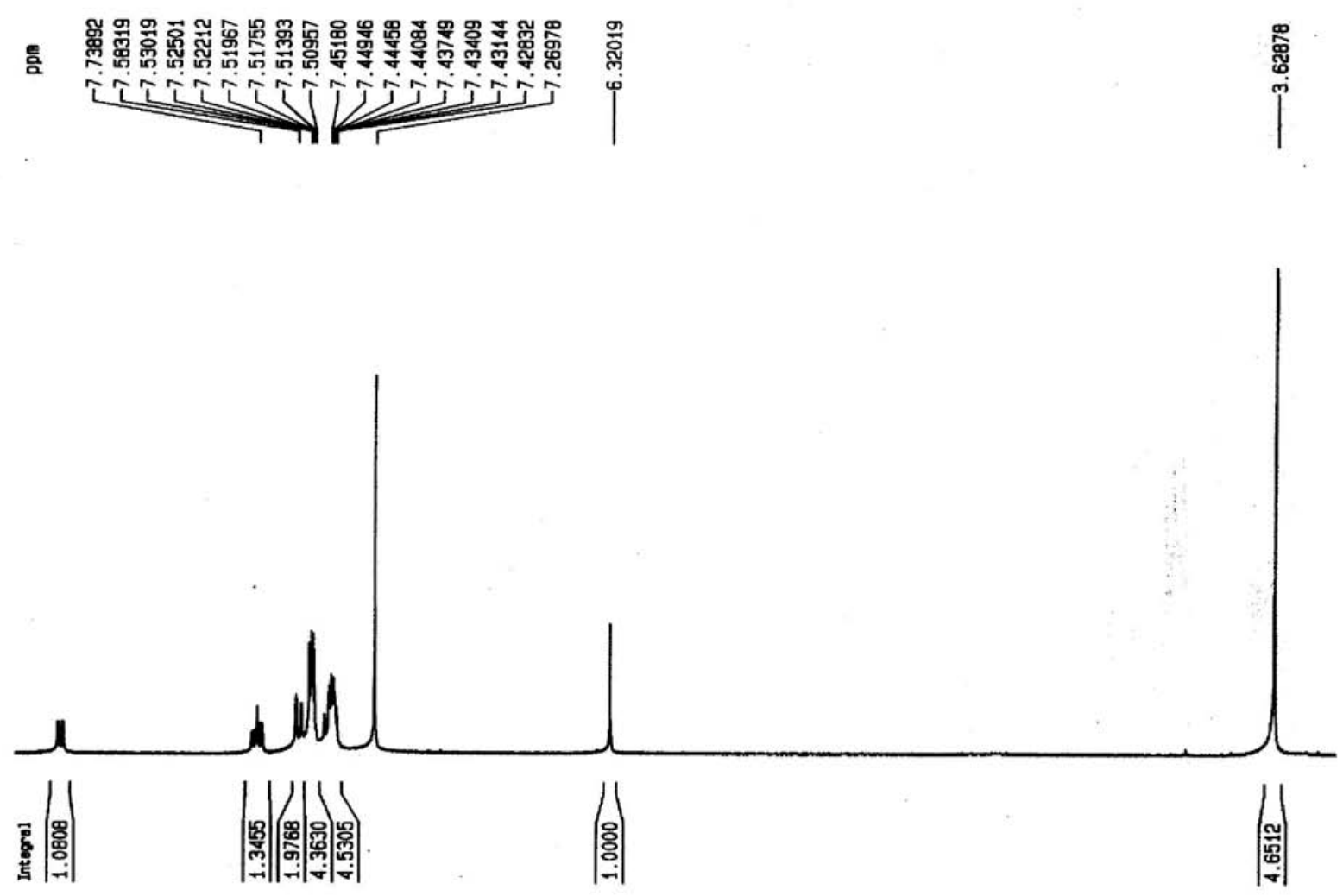

Figure S7. 'H NMR spectrum of 1-methyl-2-phenylquinolin-4-one ( $\left.\mathrm{CDCl}_{3}, 400 \mathrm{MHz}\right)$. 


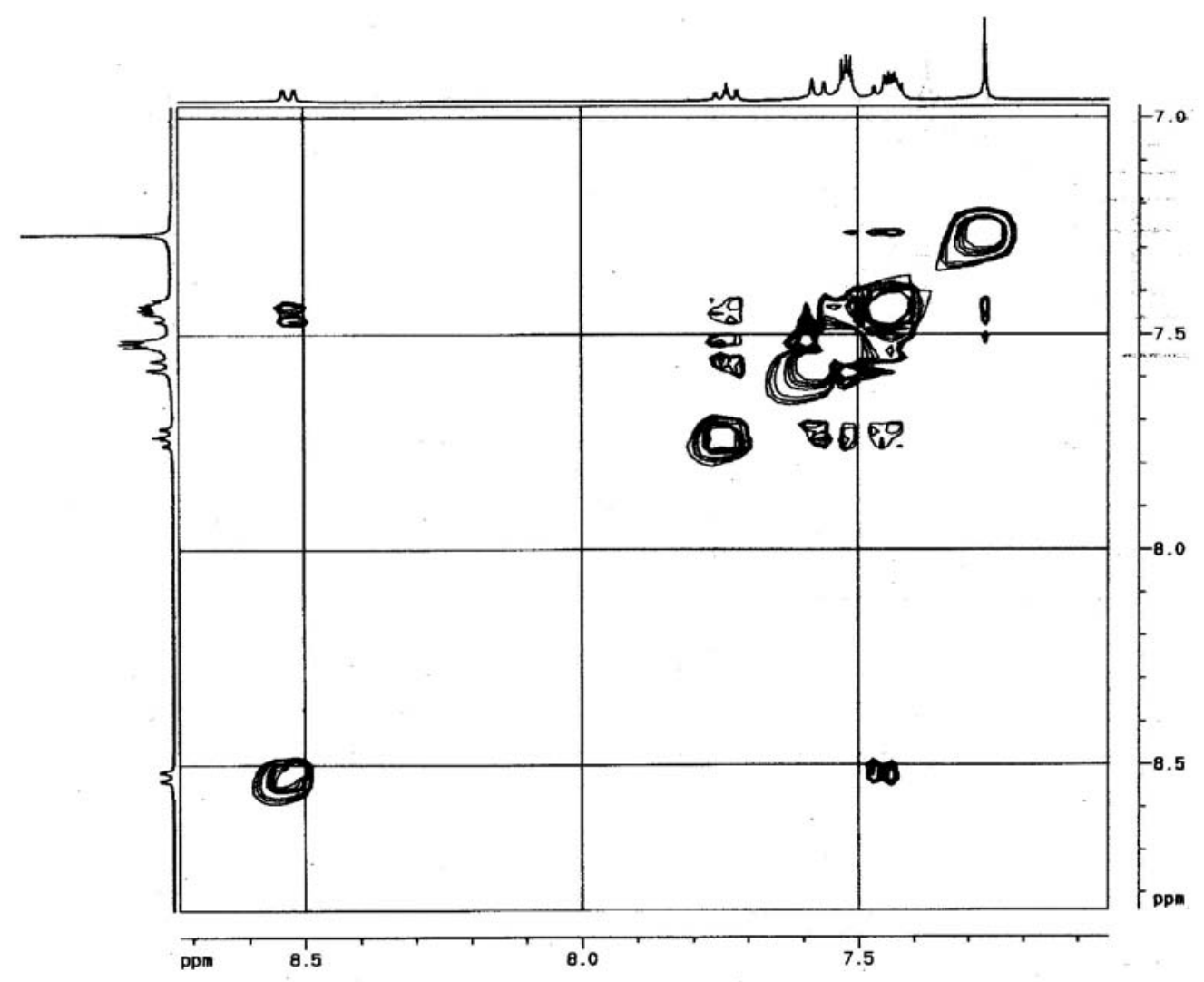

Figure S8. COSY spectrum of 1-methyl-2-phenylquinolin-4-one $\left(\mathrm{CDCl}_{3}, 400 \mathrm{MHz}\right)$.
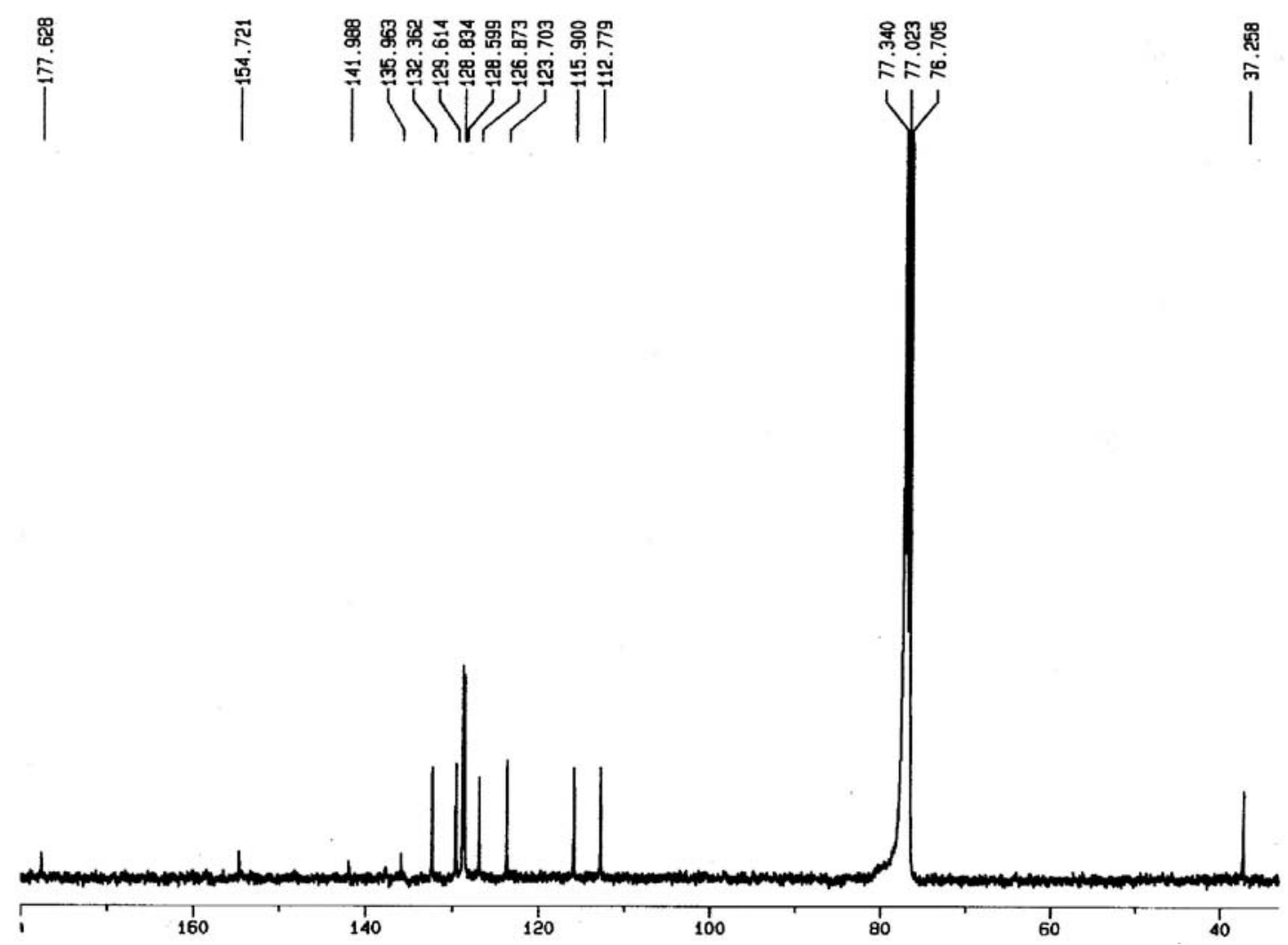

Figure S9. ${ }^{13} \mathrm{C}$ NMR spectrum of 1-methyl-2-phenylquinolin-4-one ( $\left.\mathrm{CDCl}_{3}, 400 \mathrm{MHz}\right)$. 


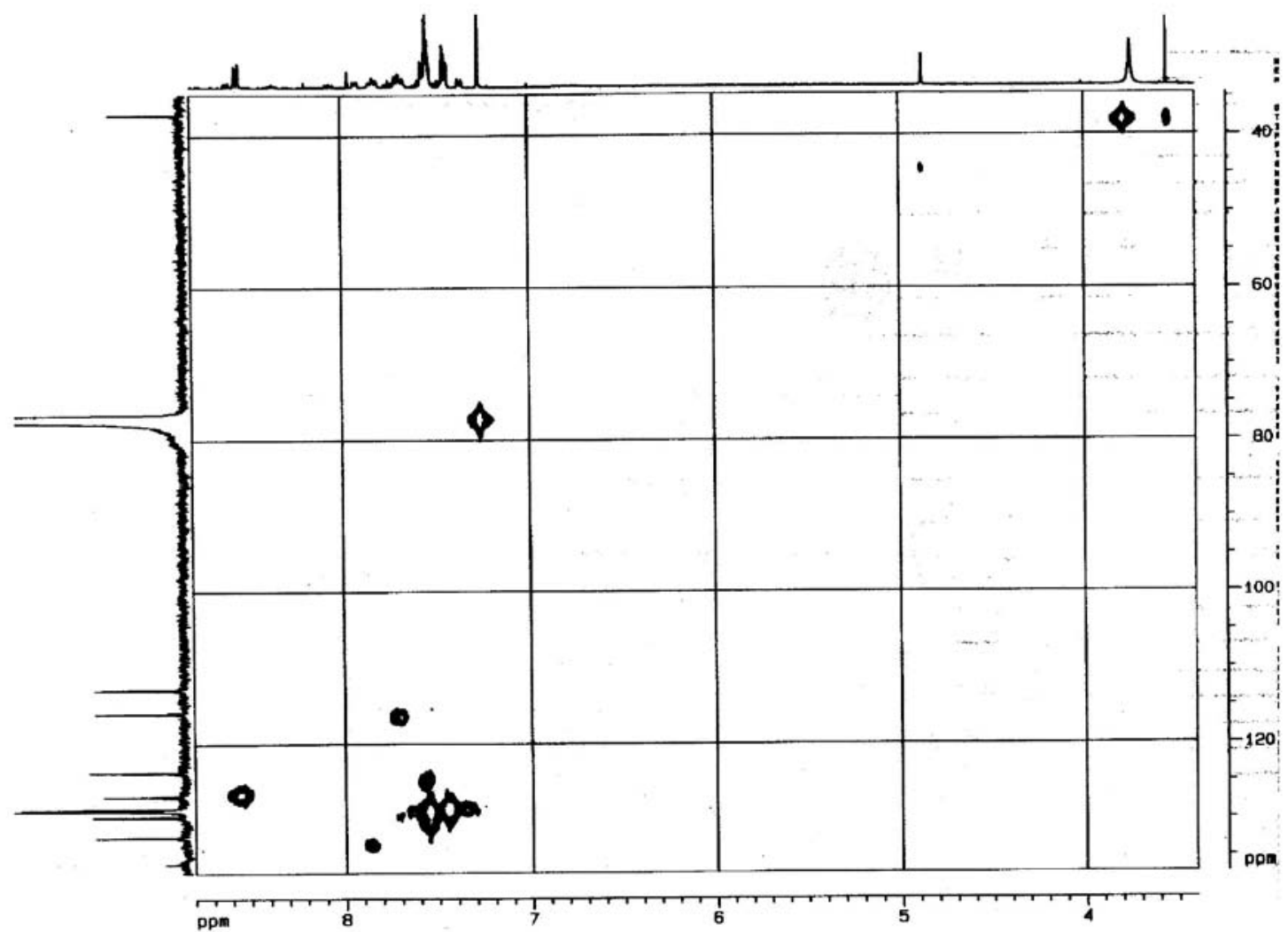

Figure S10. HSQC contour map of 1-methyl-2-phenylquinolin-4-one $\left(\mathrm{CDCl}_{3}, 400 \mathrm{MHz}\right)$.

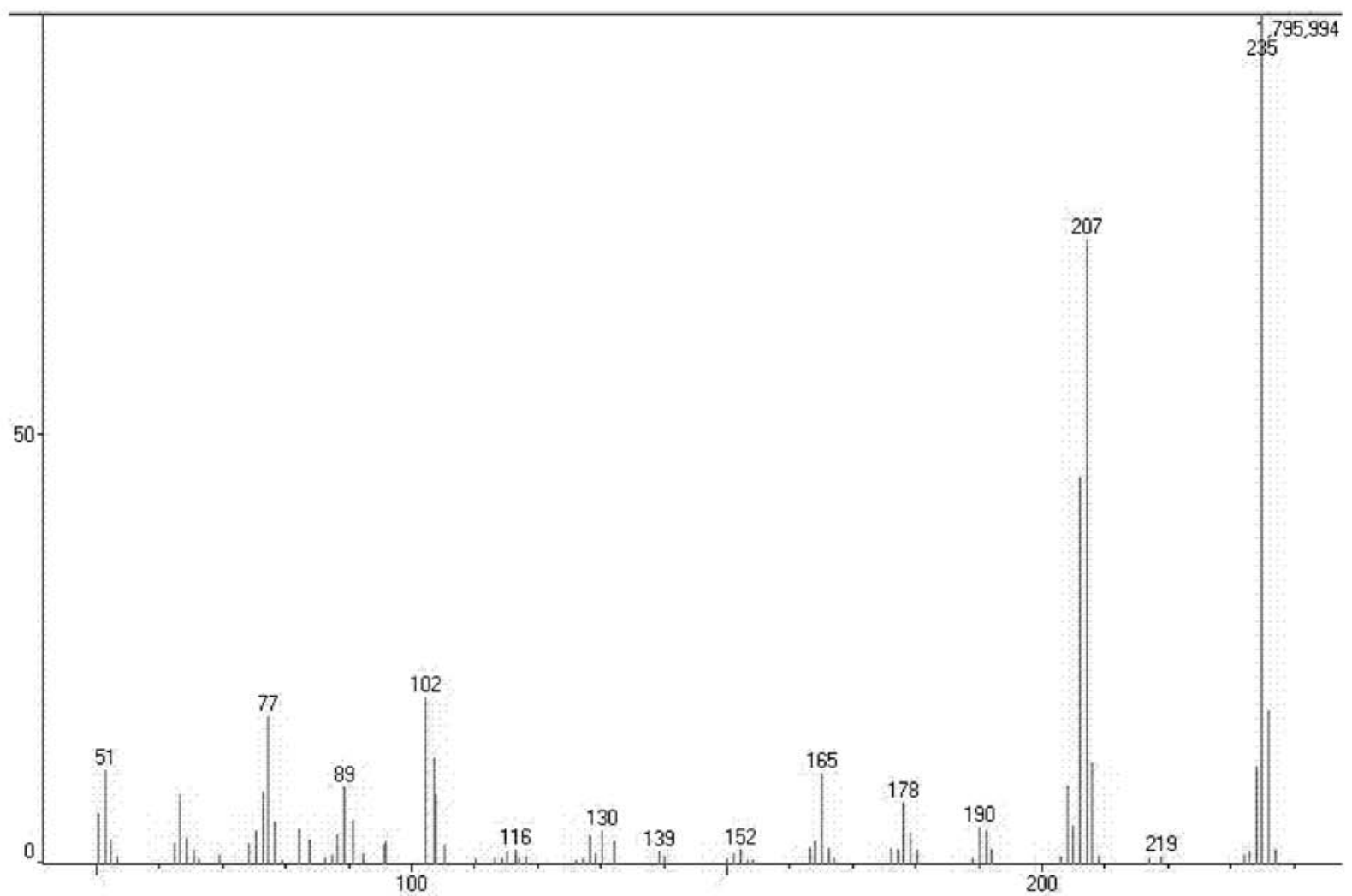

Figure S11. EIMS spectrum of 1-methyl-2-phenylquinolin-4-one. 

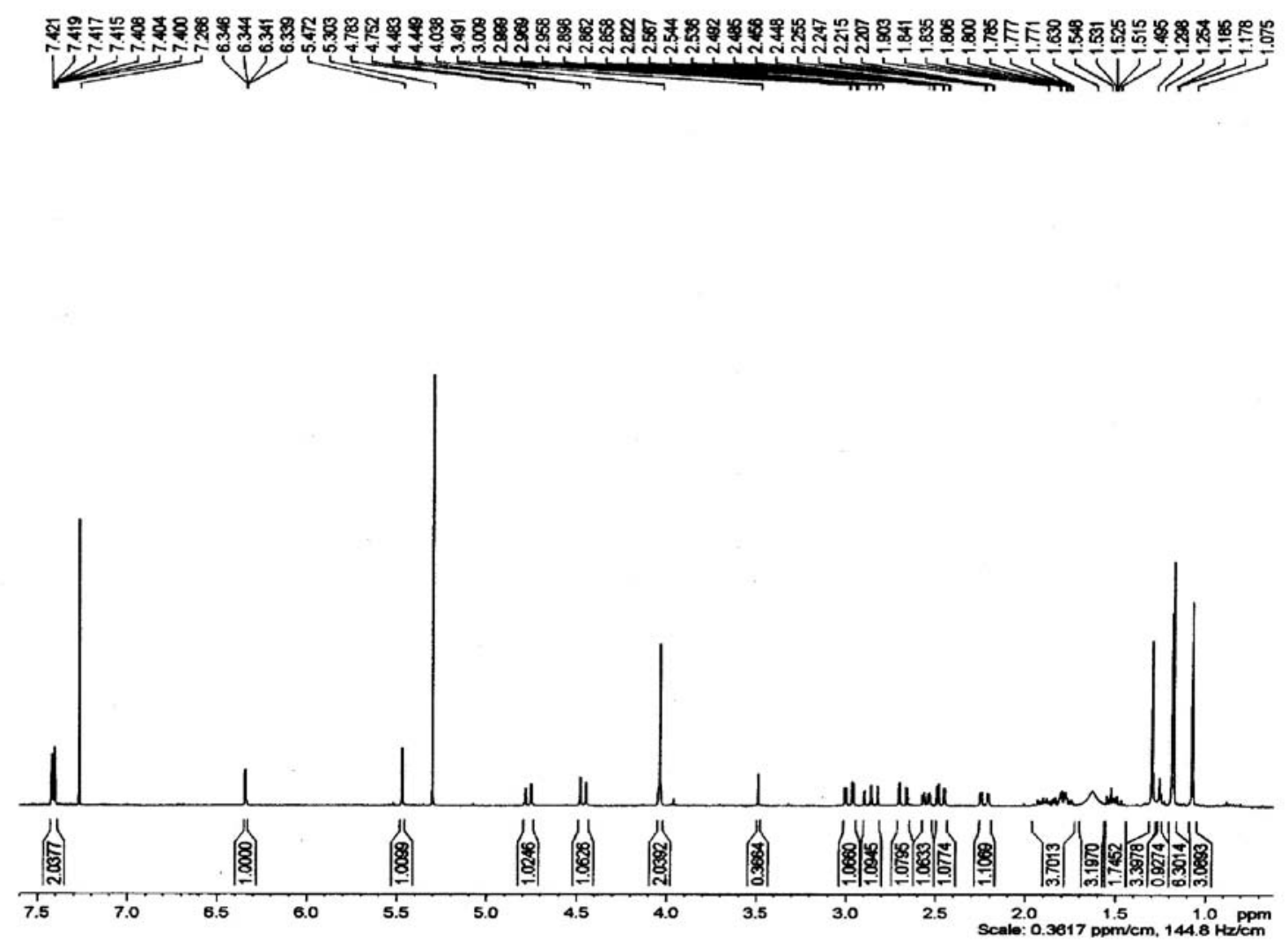

Figure S12. ${ }^{1} \mathrm{H}$ NMR spectrum of limonin $\left(\mathrm{CDCl}_{3}, 400 \mathrm{MHz}\right)$.

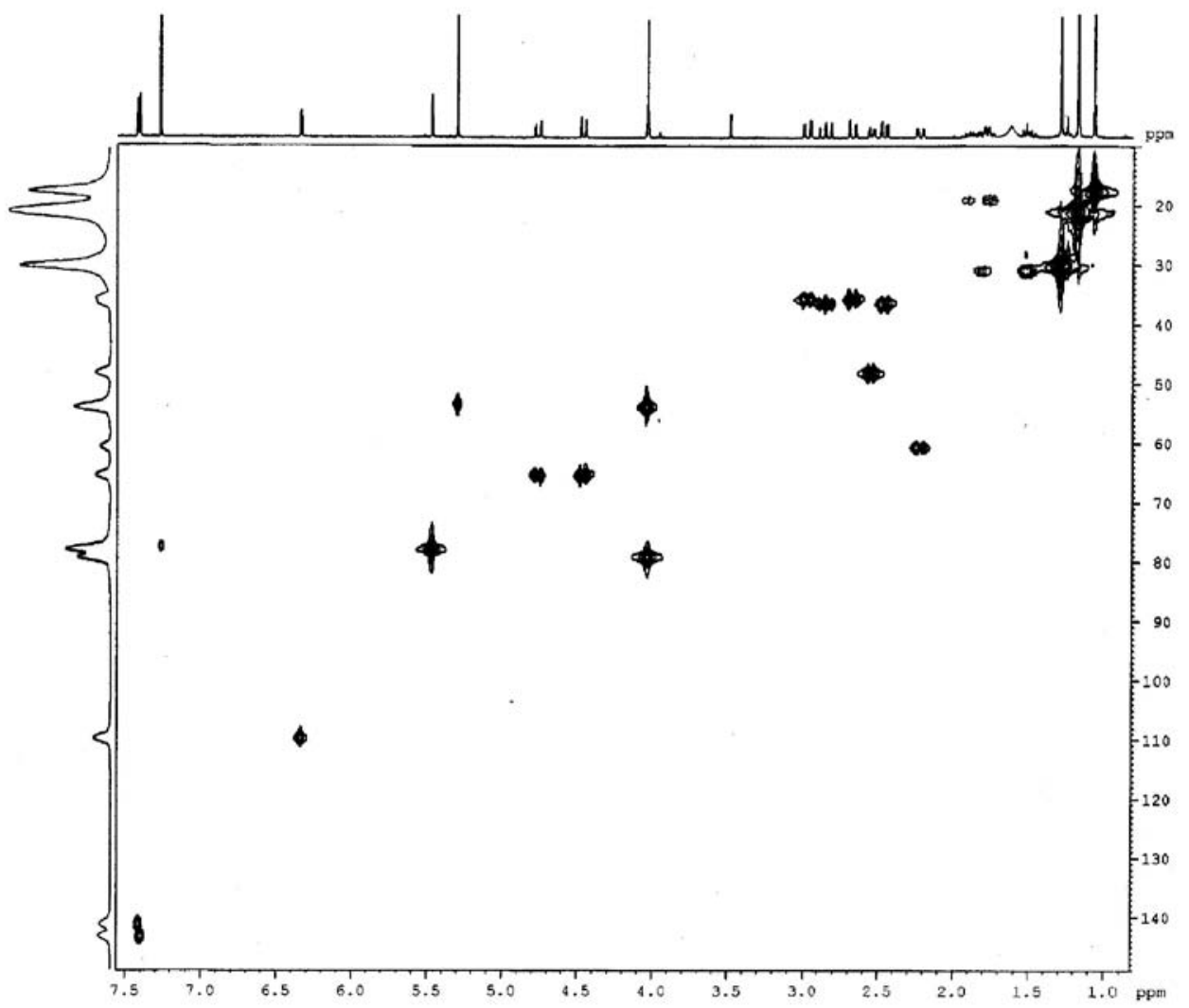

Figure S13. HSQC contour map of limonin $\left(\mathrm{CDCl}_{3}, 400 \mathrm{MHz}\right)$. 


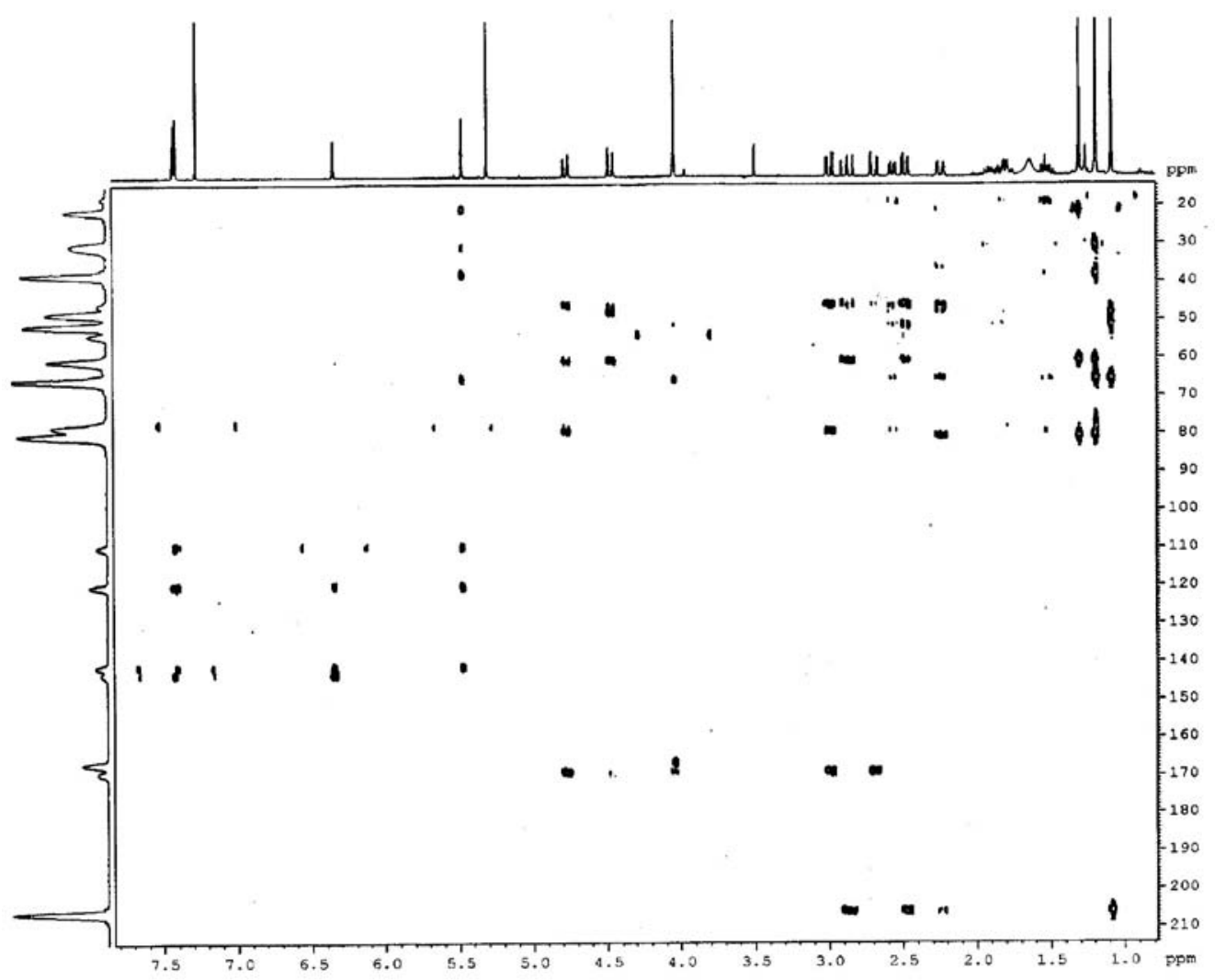

Figure S14. HMBC contour map of limonin $\left(\mathrm{CDCl}_{3}, 400 \mathrm{MHz}\right)$.

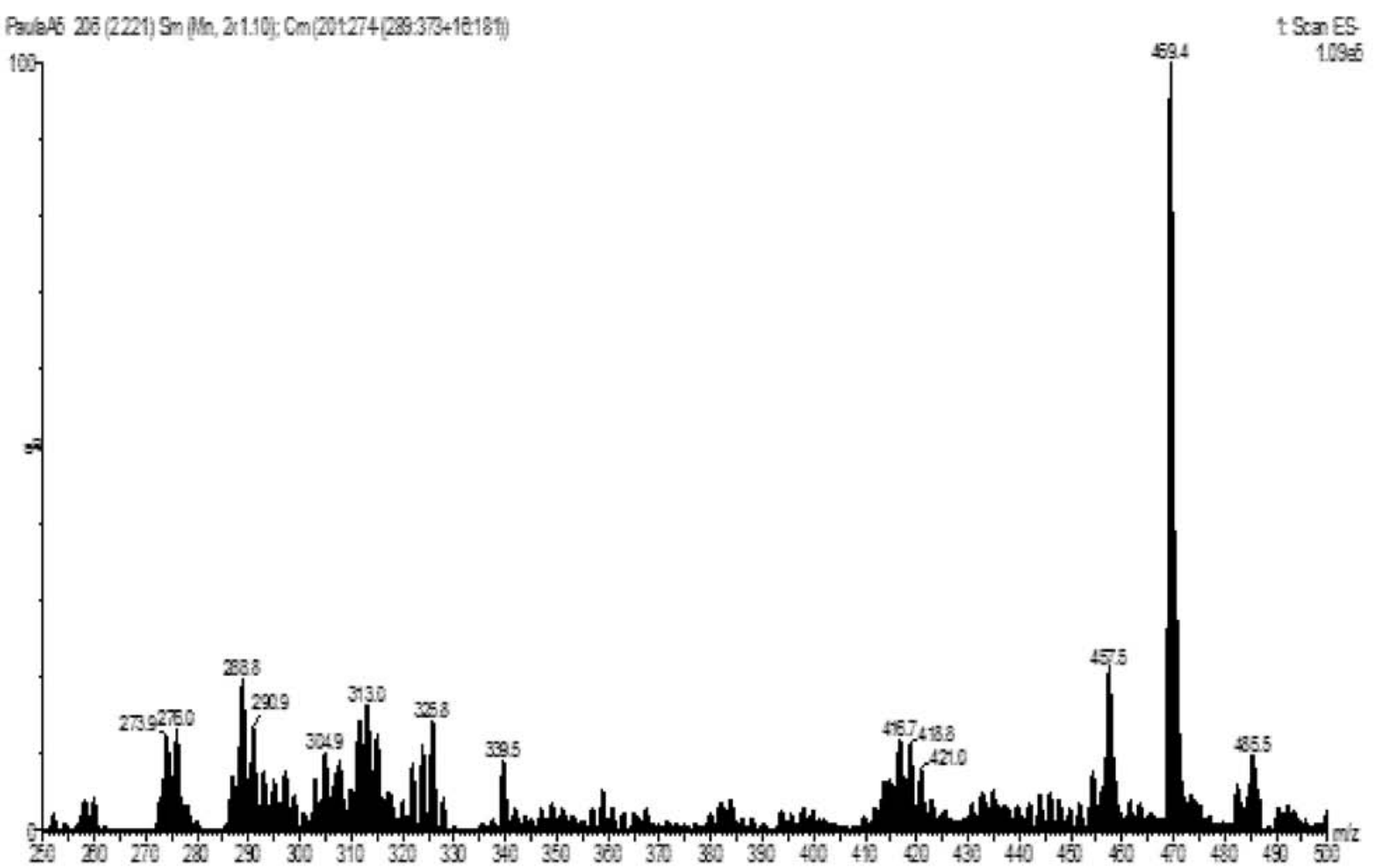

Figure S15. ESIMS spectrum of limonin (negative mode). 


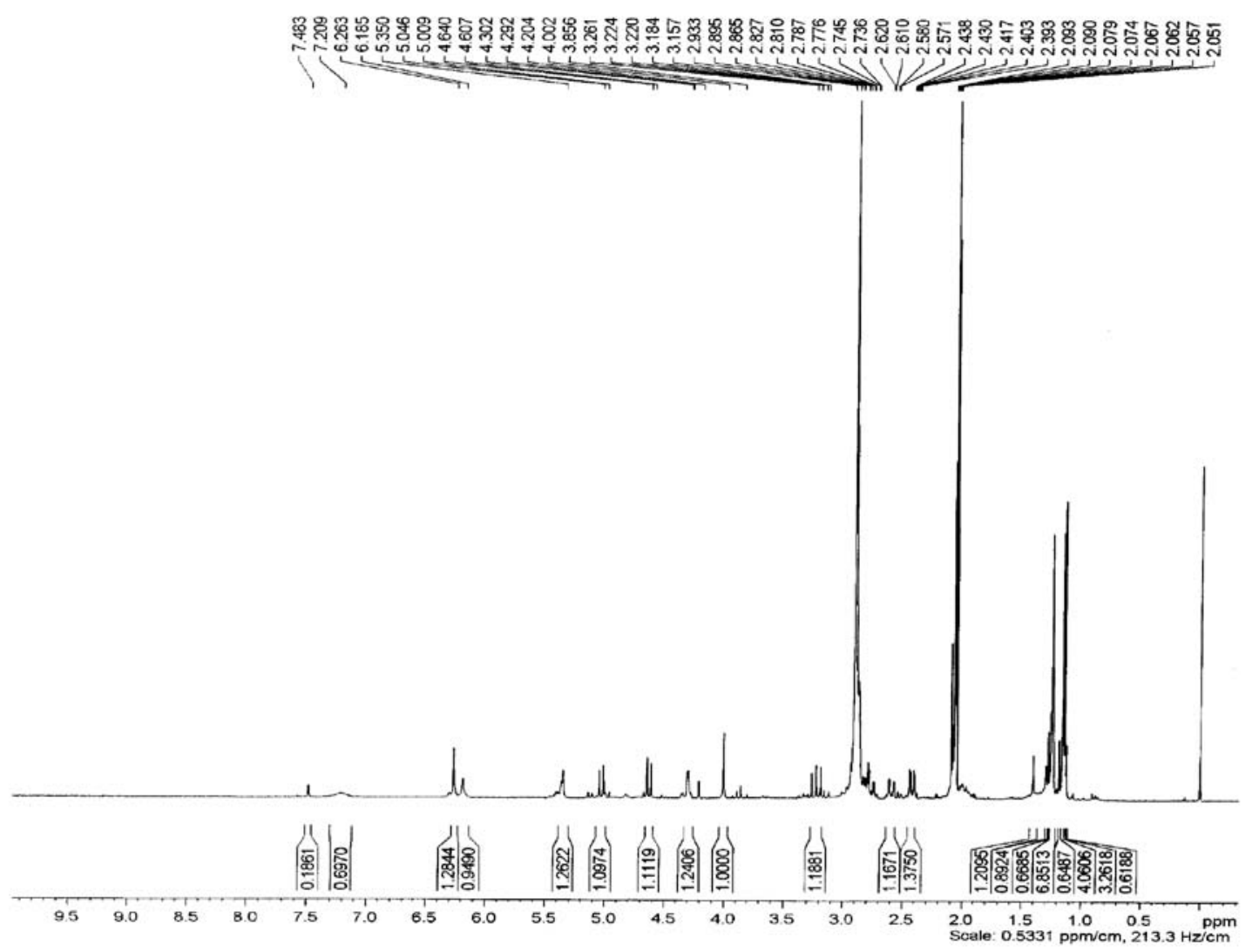

Figure S16. ${ }^{1} \mathrm{H}$ NMR spectrum of limonexic acid (acetone- $d_{6}, 400 \mathrm{MHz}$ ).

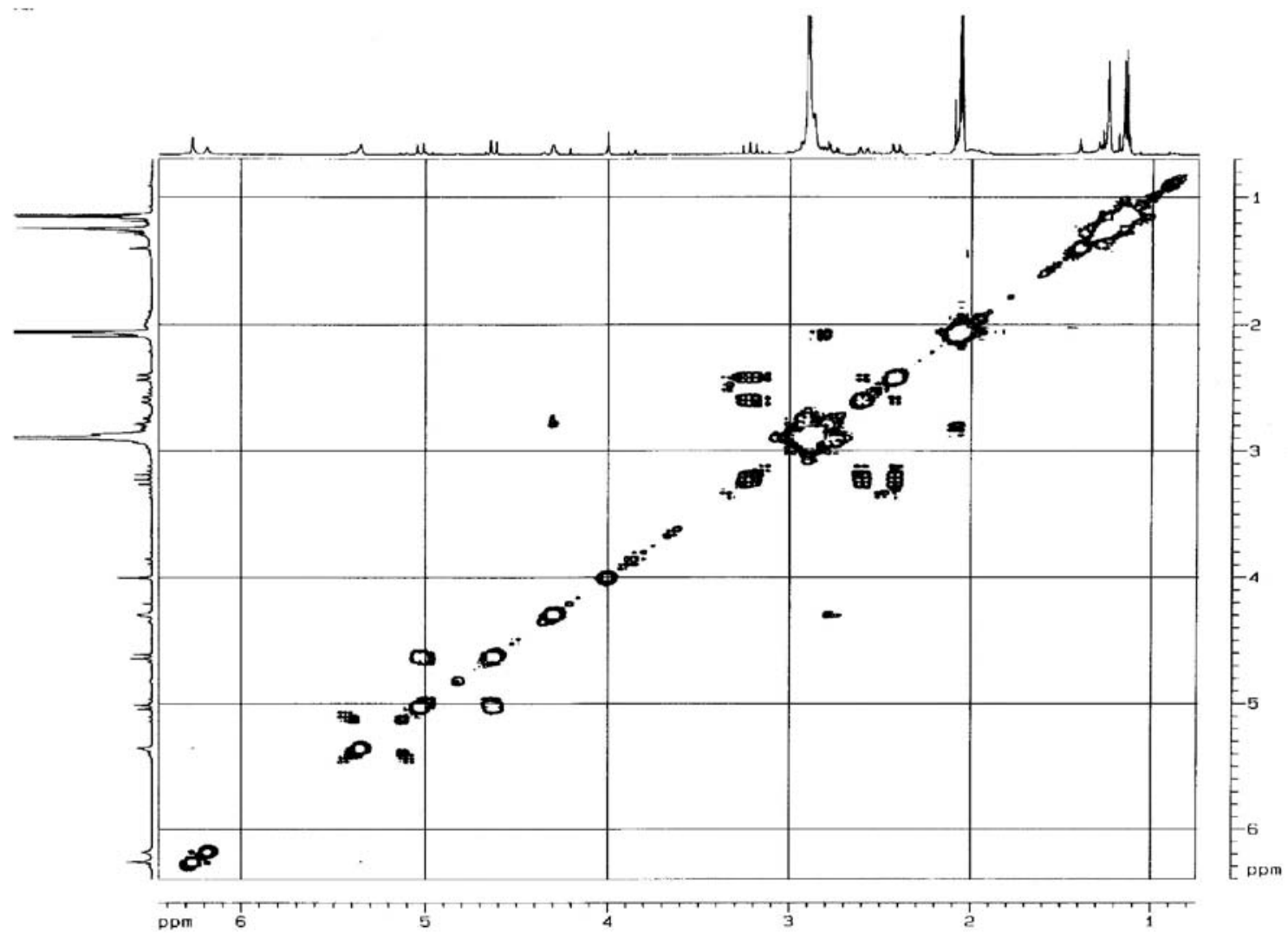

Figure S17. COSY spectrum of limonexic acid (acetone- $d_{6}, 400 \mathrm{MHz}$ ). 


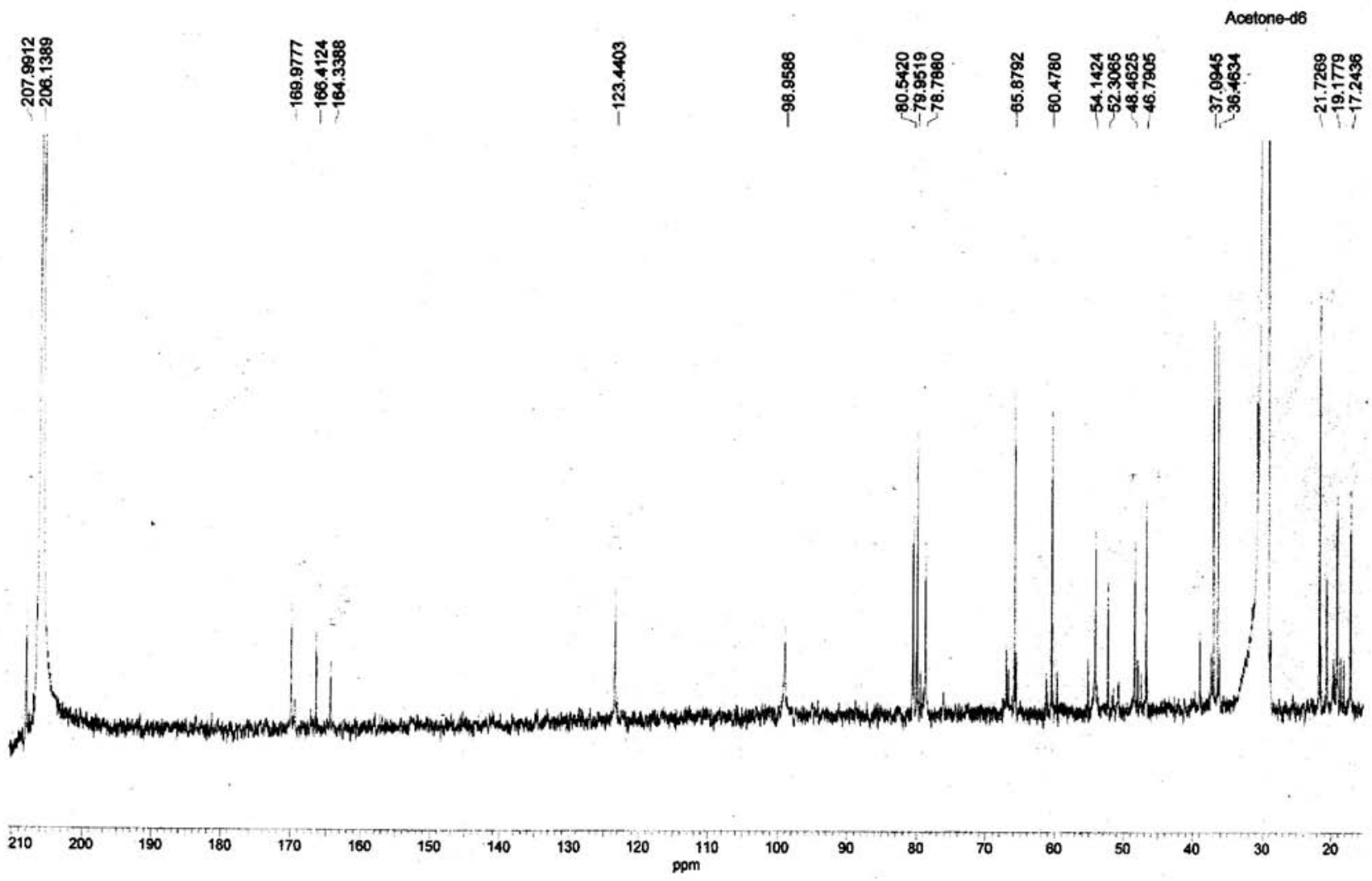

Figure S18. ${ }^{13} \mathrm{C}$ NMR spectrum of limonexic acid (acetone- $d_{6}, 400 \mathrm{MHz}$ ).

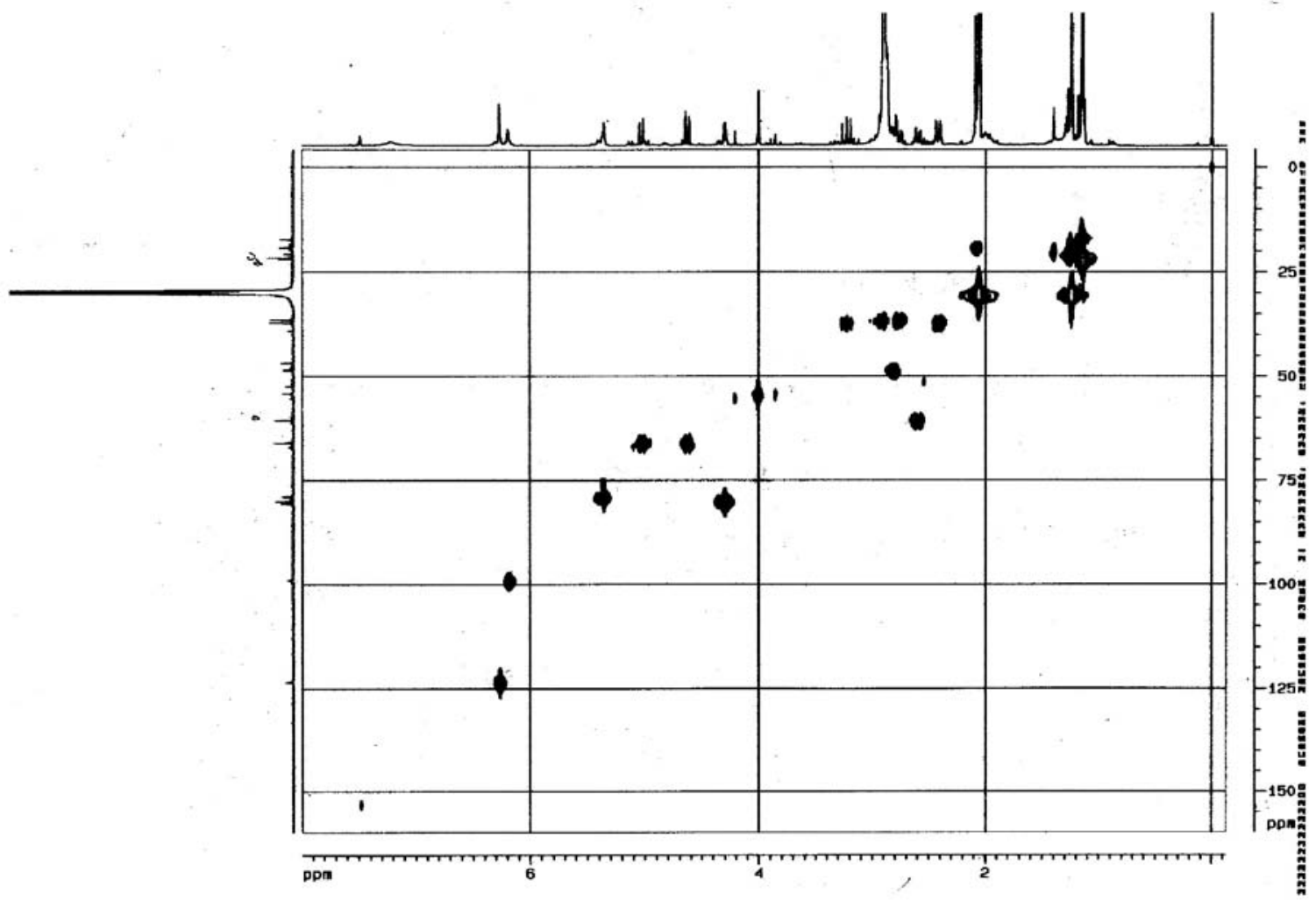

Figure S19. HSQC contour map of limonexic acid (acetone- $d_{6}, 400 \mathrm{MHz}$ ). 


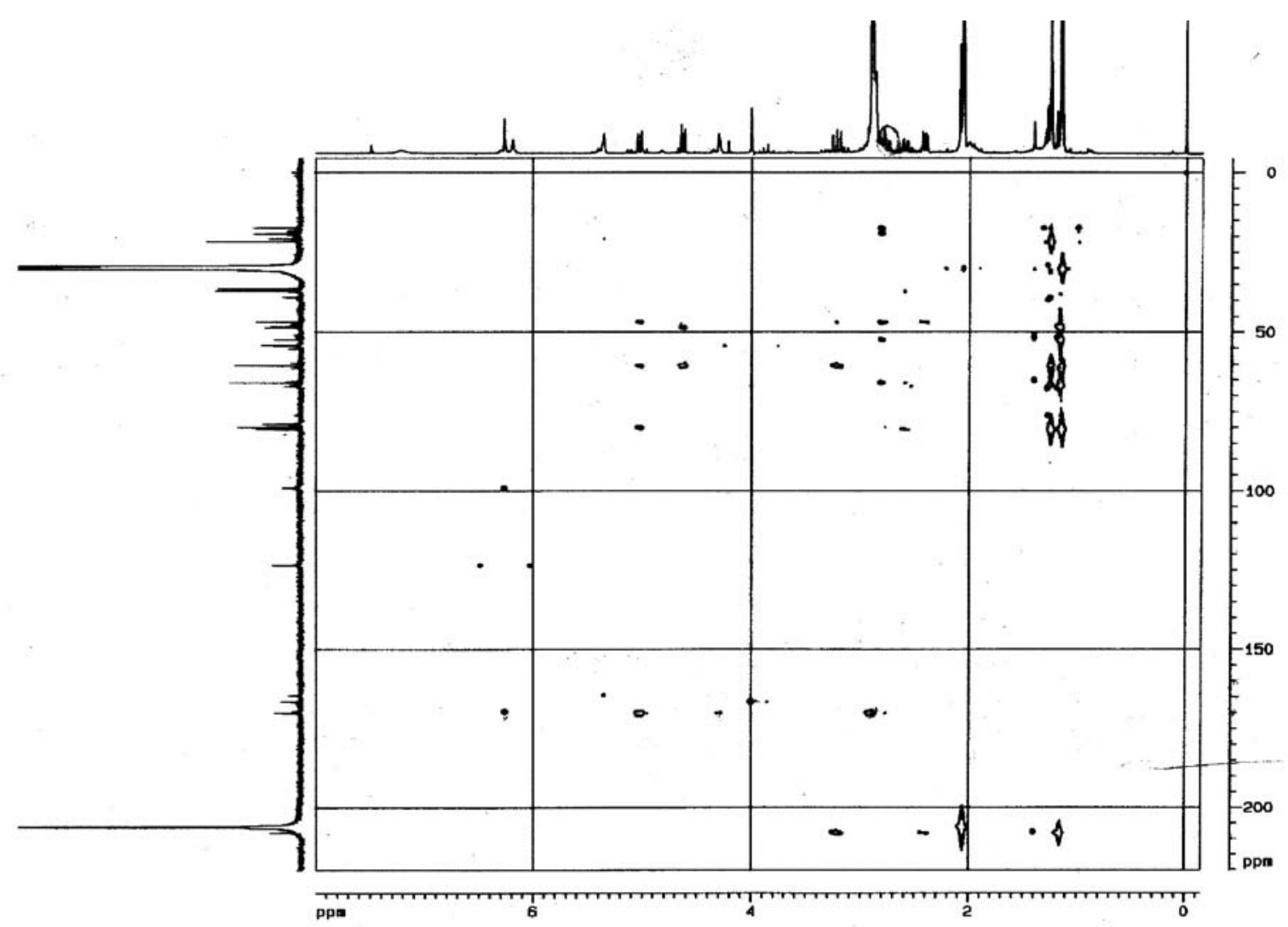

Figure S20. HMBC contour map of limonexic acid (acetone- $d_{6}, 400 \mathrm{MHz}$ ). 